Jurnal Gizi dan Dietetik Indonesia

(Indonesian Journal of Nutrition and Dietetics)

Vol. 8, No. 1, 2020: 22-29

\section{Houesehold food security is a risk factor of type 2 diabetic mellitus}

\author{
Nor Eka Noviani', BJ. Istiti Kandarina², Fatma Zuhrotun Nisa'3
}

${ }^{1}$ Nutrition Program, Faculty of Health Science, Universitas 'Aisyiyah Yogyakarta, Indonesia*

${ }^{2}$ Departement of Biostatistics, Epidemiology and Population Health, Faculty of Medicine Public Health and Nursing

Universitas Gadjah Mada, Yogyakarta, Indonesia

${ }^{3}$ Nutrition Departement, Faculty of Medicine Public Health and Nursing Universitas Gadjah Mada, Yogyakarta, Indonesia ${ }^{*}$ Corresponding author: norekanoviani@unisayogya.ac.id

\title{
ABSTRAK
}

Latar Belakang: Ketahanan pangan adalah kondisi terpenuhinya pangan bagi negara sampai dengan perseorangan, yang tercermin dari tersedianya pangan yang cukup, baik jumlah maupun mutunya, aman, beragam, bergizi, merata, dan terjangkau serta tidak bertentangan dengan agama, keyakinan, dan budaya masyarakat, untuk dapat hidup sehat, aktif, dan produktif secara berkelanjutan. Ketika kondisi pangan bagi negara sampai dengan perorangan tidak terpenuhi, maka kondisi yang terjadi adalah tidak tahan pangan. Tidak tahan pangan berhubungan dengan penyakit kronis diabetes melitus tipe 2.

Tujuan: Tujuan penelitian ini adalah untuk mengidentifikasi ketahanan pangan dan faktor lain yang berhubungan dengan DM2 di Kulon Progo, Yogyakarta, Indonesia.

Metode: Penelitian ini adalah penelitian obeservasi dengan desain case control, dimana kasus adalah pasien diabetes melitus tipe 2 yang terdaftar di 4 kecamatan di Kabupaten Kulon Progo. Sedangkan kontrol adalah subyek bukan penyandang DM2. Penentuan sampel menggunakan metode purposive yang kemudian dilakukan penyetaraan terhadap umur dan tempat tinggal. Uji statistik chi-square, Mc. Nemar dan regresi logistik dilakukan untuk mengidentifikasi variabel yang merupakan faktor risiko.

Hasil: Uji chi square menunjukkan bahwa riwayat keluarga memiliki hubungan yang bermakna dengan DM2 ( $p<0,05)$. Status tidak tahan pangan lebih banyak terjadi pada kelompok kontrol $(79,36 \%)$. Banyak responden memiliki skor kualitas diet yang kurang yakni 60,32\% di kedua kelompok. Banyak responden tidak mengalami obesitas (>50\%). Obesitas sentral terjadi pada 65,08\% kasus dan 52,38\% kontrol. Uji Mc. Nemar menunjukkan tidak ada variabel yang signifikan ( $p>0,05 ;$ OR $>1)$. Obesitas sentral berisiko terjadinya DM2 sebesar 61\%. Uji regresi logistik menyimpulkan bahwa riwayat keluarga memberikan kontribusi besar berkembangnya DM2.

Kesimpulan: Ketahanan pangan rumah tangga bukan faktor risiko terjadinya DM2 di Kulon Progo. Obesitas sentral berpeluang terjadinya DM2. Faktor genetik sebagai faktor dominan terjadinya DM2 di Kulon Progo.

KATA KUNCI: diabetes melitus tipe 2; ketahanan pangan; kualitas diet; obesitas; obesitas sentral; faktor risiko

\section{ABSTRACT}

Background: Food security reflects a situation when individual at all times has physical, social, and economic access to sufficient, diversified, safe and nutrious food that meets their dietary needs, food preference and religious believes for an active and healthy life. When the condition of individual is not adequate, it will contribute to food insecurity. Food insecurity has association with chronic diseases like type 2 diabetic mellitus (DM2).

Objectives: To identify whether food security and other cofactors being the risk of DM2 in Kulon Progo Regency, Yogyakarta, Indonesia.

Methods: This is an observational study with case control design. The case group was diabetic patients registered in Community Health Center in 4 subdistrics in Kulon Progo Regency whereas the control group was non diabetic patients. Respondents were selected purposively in accordance with inclusive and exclusive criterion, equivalently matching with age, gender and neighborhood. Chi square test, Mc. Nemar and logistic regression were used to identify risk factor. 
Results: The characteristic of two group revealed that family history had significant association in development of DM2 ( $p<0.05)$. Food insecurity more commonly occured in control group (79.36\%). Low quality diet was faced by the two group. Half of them had no obesity. Based on Mc. Nemar no variables statistically became risk factor of diabetic mellitus type 2 ( $p>0.05)$. But central obesity can be risk for DM. Genetic factor contributed to be DM2.

Conclusion: Food security was not risk factor of developing DM2. Central obesity might be the risk of DM2. Parent history was the dominant factor of DM2.

KEYWORDS: diabetic mellitus; food security; quality diet; obesity; risk factor

\section{INTRODUCTION}

Food security reflects a situation when individual at all times has physical, social, and economic access to sufficient, diversified, safe and nutritious food that meets their dietary needs, food preference and religious believes for an active and healthy life (1). Food insecurity occurs when food condition in individual is not available. House hold food insecurity happened when access of safe and adequate food was limited, uncertain or depended on supply of emergency food, scavenging or stealing (2).

Food insecurity was related to worsen health status, including type 2 diabetic mellitus. It was also influenced by genetic factor. World Health Organization said the first offspring of individual with type 2 diabetic mellitus had 3 bigger risk than that without family history. Although genetic factor had a big impact on the development of diabetic, environmental factors also contributed to the illness (3).

The epidemiological change in food pattern, physical activities and body composition has rapidly grown in many developing countries (4). Rapid changes in socioeconomic factor with increase in urbanization and dietary habit have alternated food pattern in Asia Pacific. Experiences in China, Japan and Korea have showed trend incident in chronic degenerative diseases like obesity, stroke, cancer and osteoporosis. Dietary habit changed food pattern with complex carbohydrate from grain, low fat to that with high density caloric food by increase of consuming animal products, fat and sugar. It was also added by decrease of complex carbohydrate.

Surely, Indonesia has also experienced nutrition transition. The scope encompasses not merely the dietary and physical aspect, but many other economic, social and environment factors also. The nutrition transition characterized by a shift from traditional high carbohydrate, low fat diets towards diet with a lower carbohydrate and higher proportion of saturated fat, sugar and salt. Since the 1960's, there has been a fast shift in economic sector. It could have been changed socio demographic structure and affected food pattern in the country (5).

Based on these problems, this study aims to analyze what household food insecurity, quality diet and obesity are risk factors of type 2 diabetic mellitus.

\section{MATERIALS AND METHODS}

It was an observational method with case control design. Respondents of case were type 2 diabetic patients without complication registered at community health center in Kulon Progo Regency, Yogyakarta Province, Indonesia. Whereas those of control were individual without type 2 diabetic mellitus living in the same place as those of case matching with age and gender. Patients with type 2 diabetic mellitus were obtained from the data of 4 center health communities in Sentolo, Wates, Samigaluh and Kalibawang districts representing the geographical of Kulon Progo Regency including low, middle and high (plateau) area respectively. The research was held for almost 2 months from September- November 2015. The research had approved by Ethical Committee in Faculty of Medicine with the number KE/FK/1226/EC/2015. Data of case group were from patients with type 2 diabetic mellitus visiting the center health communities in the last 3 months and selected purposively. Whereas, data of control group was someone without type 2 diabetic mellitus obtained 
by matching with age, sex, marital status and living in the same village. The number of case and control group was 63 respondents respectively.

Food security was resulted from interview by validated Radimer/Cornel Questionnaire. It consisted of 9 Yes-No questions answered by house wife. The answer then categorized based on secure and insecure conditions(6).

Food access was ability to fulfill enough food based on needs compared with income and purchasing power. Food access was measured by food expenditure using national economic survey questionnaire(7). Food access was calculated with the percentage of $60 \%$ of total expenditure in categorized in low and high access.

Food absorption was output of food security by counting nutrition status of family member between case and control(8). It was based on the majority of nutrition status in family member based on age. If family member represented malnutrition it will categorized in low condition respectively. Obesity was counted by Body Mass Index with counting weight divided into heigh square. Whereas, central obesity was derived from counting waist circumference. Obesity was determined by Body Mass Index for Asian Population. Central obesity was determined by cut off for Asian population(9).

Physical activity was measured by interviewing respondents by International Physical Activity Questionnaire (IPAQ). The Questionnaire consisted of type activity in the last three months. Score of physical activity was based on IPAQ Scoring Protocol.

Semi Quantitative Food Frequency Questionnaire was used to count quality diet by Diet Quality Index(10)(11). Socio economic factors included house hold income, occupation of wife and husband, education and family members. Genetic factor from family history was also included in the research.

Data were analyzed using Chi square and Fisher Exact tests for comparison of proportions among case and control groups. Mc Nemar test was used to produce odd ratios in estimating risk factor of type 2 diabetic mellitus. Last, to get the best model of the main risk factor of type 2 diabetic, we used logistic regression.

\section{RESULTS}

\section{Characteristic of respondents}

There were 126 respondents of case and control groups in Kulon Progo Regency, matching with age, gender and the same place. Respondents mainly was female $(67 \%)$. On the other hand, the average of age in case was 49.6 years old where that of control was 50 years old. From income aspect, more respondents had low income. The percentage of parents' income (<3.2 million) was 65.1 and 74.6 in case and control respectively. Statistically, there was no different association between two groups $(p>0.05)$. Many of respondents in the groups did not mainly pass from senior high school. The association between two groups statistically was not significant. Based on agricultural sector, almost all head family mostly worked on agricultural sector in case and the groups that was $56.5 \%$ and $53.2 \%$ in case and control groups respectively. Statistically, there was no different association between father's work in two groups. Most of mothers was as house wife, whereas only 39.7 percent of mothers in two groups worked. There was no significant relationship between two groups. Family members was not significant also between the groups. The number of family size mostly was less than 4 members. It did not have significant association between two group.

Family history having type two diabetic mellitus was significant association. Respondents having genetic factors risked to be DM by 10.5 compared to no having family history. Only few respondents smoked, which was only 11.1 and 12.7 in case and control respectively. Based on food access, the proportion of family having high access was $84.1 \%$ in case and $77.8 \%$ in control. It had no significant association in development of DM2. Many family also had high food absorption (69.9 in case and 58.7 in control group) meaning that most of them had over nutrition status. High food absorption had $62 \%$ risk to be DM2. Physical activity did not have association statistically. Respondents had middle activity, around $44.5 \%$ and $47.6 \%$ in case and control groups. 
Table 1. Characteristics of Respondents Among Case and Control Groups

\begin{tabular}{|c|c|c|c|c|c|c|}
\hline \multirow{2}{*}{ Characteristic } & \multicolumn{2}{|c|}{ Case } & \multicolumn{2}{|c|}{ Control } & \multirow{2}{*}{$\mathbf{p}$} & \multirow{2}{*}{ OR $95 \% \mathrm{Cl}$} \\
\hline & $\mathbf{N}$ & $\%$ & $\mathbf{N}$ & $\%$ & & \\
\hline \multicolumn{7}{|l|}{ Family income } \\
\hline Low & 41 & 65.1 & 47 & 74.6 & \multirow[t]{2}{*}{0.3} & 0.6 \\
\hline High & 22 & 34.9 & 16 & 25.4 & & $0.3-1.5$ \\
\hline \multicolumn{7}{|l|}{ Respondent's education } \\
\hline$\leq 9$ year & 32 & 50.8 & 38 & 60.3 & \multirow[t]{2}{*}{0.3} & 0.7 \\
\hline$>9$ year & 31 & 49.2 & 25 & 39.7 & & $0.3-1.5$ \\
\hline \multicolumn{7}{|l|}{ Headmaster's Occupation } \\
\hline Agrarian & 35 & 56.5 & 29 & 46.7 & \multirow[t]{2}{*}{0.3} & 1.5 \\
\hline Non agrarian & 28 & 44.5 & 34 & 53.3 & & $(0.7-3.1)$ \\
\hline \multicolumn{7}{|l|}{ Wife's occupation } \\
\hline housewife & 24 & 60.3 & 24 & 60.3 & \multirow[t]{2}{*}{0.9} & 1.1 \\
\hline active work & 37 & 39.7 & 39 & 39.7 & & $0.5-2.3$ \\
\hline \multicolumn{7}{|l|}{ Family member } \\
\hline$\geq 4$ & 15 & 23.8 & 12 & 19.1 & \multirow[t]{2}{*}{0.5} & 1.3 \\
\hline$<4$ & 48 & 76.2 & 51 & 80.9 & & $0.5-3.4$ \\
\hline \multicolumn{7}{|l|}{ Food Access } \\
\hline Low & 10 & 15.9 & 14 & 22.2 & \multirow[t]{2}{*}{0.4} & 0.7 \\
\hline High & 53 & 84.1 & 49 & 77.8 & & $0.2-1.8$ \\
\hline \multicolumn{7}{|l|}{ Food Absorbtion } \\
\hline Low & 5 & 8.0 & 20 & 31.8 & 0.2 & 1.6 \\
\hline Normal & 14 & 22.2 & 6 & 9.5 & \multirow[t]{2}{*}{0.2} & 1.6 \\
\hline High & 44 & 69.8 & 37 & 58.7 & & \\
\hline \multicolumn{7}{|l|}{ Family History of DM2 } \\
\hline Yes & 33 & 52.4 & 6 & 9.5 & \multirow[t]{2}{*}{$0.0^{\mathrm{a}}$} & 10.5 \\
\hline No & 30 & 47.6 & 57 & 90.5 & & $3.7-33.3$ \\
\hline \multicolumn{7}{|l|}{ Smoking Status } \\
\hline Yes & 7 & 11.1 & 8 & 12.7 & \multirow[t]{2}{*}{$0,5^{b}$} & 0,85 \\
\hline No & 56 & 88.9 & 55 & 87.3 & & $0.3-2.9$ \\
\hline \multicolumn{7}{|l|}{ Physical Activity } \\
\hline Low & 27 & 42.9 & 19 & 30.2 & 0.2 & 0.5 \\
\hline Middle & 28 & 44.5 & 30 & 47.6 & \multirow[t]{2}{*}{0.1} & 0.6 \\
\hline High & 8 & 12.6 & 14 & 22.2 & & \\
\hline
\end{tabular}

Information: asignifikan $p<0,05$, ${ }^{b}$ fisher exact

\section{Food Security, Quality Diet, Obesity and Type Two Diabetic Mellitus.}

Food insecurity was experienced by 66.67 and 79.36 in case and control respectively. Respondents having low quality diet were $60.32 \%$ in case and control group. The percentage of obesity was faced by less than fifty percent of all respondents. However, central obesity was faced by respondents in the two group, $65 \%$ in case and $52.38 \%$ in control.

Based on Mc Nemar test, the four variables did not have significant correlation with development of type 2 diabetic mellitus ( $p>0.05$ ). Food security did not became risk factor of type 2 diabetic mellitus where the odd ratio was 0.46 . Diet quality and obesity did not have significant association also.
Their odd ratio was 1 and 0.8 respectively. On the other hand, central obesity might be the risk of type 2 diabetic mellitus, having $28 \%$ higher in respondent with food security.

\section{Factors in development of type two diabetic mellitus}

Based on logistic regression, family history and food security had significant correlation $(p<0,05)$. Respondents having family history risked to be type two diabetic mellitus by 11,95 times more. In contrast, food security was protective factor, because genetic factors had main role in developing DMT2. 
Table 2 Mc Nemar Analysis of Determinants Food Security and Type 2 Diabetic Mellitus

\begin{tabular}{|c|c|c|c|c|c|}
\hline \multirow{4}{*}{ Case } & \multirow{2}{*}{ Food Security } & \multicolumn{2}{|c|}{ Control } & \multirow{2}{*}{$\begin{array}{c}\text { OR } \\
95 \mathrm{Cl}\end{array}$} & \multirow{2}{*}{$\mathbf{P}$} \\
\hline & & Insecure & Secure & & \\
\hline & Secure & 35 & 7 & 0.5 & 01 \\
\hline & Insecure & 15 & 6 & $0.2-1.1$ & 0.1 \\
\hline \multirow{4}{*}{ Case } & \multirow{2}{*}{ Quality Diet } & \multicolumn{2}{|c|}{ Control } & OR & $P$ \\
\hline & & Low & Moderate & $95 \mathrm{Cl}$ & $P$ \\
\hline & Less & 27 & 11 & & \\
\hline & Moderate & 11 & 1 & 1 & 1 \\
\hline \multirow{4}{*}{ Case } & \multirow{2}{*}{ Obesity } & \multicolumn{2}{|c|}{ Control } & OR & $P$ \\
\hline & & Yes & No & $95 \mathrm{Cl}$ & $P$ \\
\hline & Obes & 33 & 12 & 0,8 & 07 \\
\hline & No Obes & 15 & 3 & $0.4-1.7$ & 0.1 \\
\hline \multirow{4}{*}{ Case } & \multirow{2}{*}{ Central Obesity } & \multicolumn{2}{|c|}{ Control } & OR & $\mathrm{P}$ \\
\hline & & Yes & No & $95 \mathrm{Cl}$ & $P$ \\
\hline & Yes & 20 & 21 & 1.6 & 0.2 \\
\hline & No & 13 & 9 & $0.8-3.2$ & \\
\hline
\end{tabular}

Table 3. Factor influencing type 2 Diabetic Mellitus

\begin{tabular}{lcccc}
\hline \multicolumn{1}{c}{ Variabel } & SE & P value & OR & $\mathbf{9 5 \%} \mathbf{C l}$ \\
\hline Model 1 & & & & \\
Family history & 6.9 & $0.0^{*}$ & 13.0 & $4.6-36.8$ \\
Central Obesity & 0.9 & 0.2 & 1.9 & $0.8-4.9$ \\
Food Security & 0.2 & 0.1 & 0.4 & $0.2-1.0$ \\
Food Absorbtion & 0.3 & 0.7 & 1.1 & $0.7-1.8$ \\
Physical Activity & 0.5 & 0.7 & 0.6 & $0.2-2.5$ \\
\hline Deviance (-2 log likelihood) & 68.7 & & \\
$\mathrm{R}^{2}$ & & 0.2 & & \\
\hline
\end{tabular}

* significance $p<0,05$

\begin{tabular}{lclll}
\hline Variabel & SE & P value & OR & $\mathbf{9 5 \%} \mathbf{C I}$ \\
\hline Model 2 & & & & \\
Family history & 7.0 & $0.0^{*}$ & 13.0 & $4.6-37.1$ \\
Central Obesity & 1.0 & 0.1 & 2.1 & $0.9-4.9$ \\
Food Security & 0.2 & $0.0^{*}$ & 0.4 & $0.2-1.0$ \\
Physical Activity & 0.4 & 0.6 & 0.8 & $0.2-1.8$ \\
\hline Deviance (-2 log likelihood) & 68.8 & & \\
$\mathrm{R}^{2}$ & & 0.2 & & \\
\hline
\end{tabular}

* signifikan $p<0.05$

\begin{tabular}{lclll}
\hline Variabel & SE & P value & OR & $\mathbf{9 5 \%} \mathbf{C l}$ \\
\hline Model 3 & & & & \\
Family history & 7.2 & $0,0^{*}$ & 13.5 & $4.8-38.1$ \\
Central Obesity & 0.2 & 0.1 & 2.2 & $0.9-5.0$ \\
Food Security & 0.9 & $0,0^{*}$ & 0.4 & $0.2-0.9$ \\
\hline Deviance (-2 log likelihood) & 68.9 & & \\
$\mathrm{R}^{2}$ & & 0.2 & & \\
\hline
\end{tabular}

* significance $p<0.05$

\begin{tabular}{lllll}
\hline \multicolumn{1}{c}{ Variabel } & SE & P value & OR & $\mathbf{9 5 \%} \mathbf{~ C l}$ \\
\hline Model 4 & & & & \\
Family history & 6.1 & $0,0^{*}$ & 12.0 & $4.4-32.6$ \\
Food Security & 0.2 & $0,0^{*}$ & 0.4 & $0.2-0.9$ \\
\hline Deviance (-2 log likelihood) & 70.5 & & \\
$\mathrm{R}^{2}$ & & 0.2 & & \\
\hline * significance $\mathrm{p}<0.05$ & & & &
\end{tabular}

\section{DISCUSSION}

\section{Determinants of Development Type 2 Diabetic Mellitus}

Respondents attending the research were 49.57 years of age where they were on $40-59$ years old having $87,30 \%$ percentage of all. The research in Nigeria (2012) revealed the highest prevalence of type 2 diabetic mellitus was 46-60 years(12). Based on Health Based Research in 2013, females also became the most proportion being DM2(13).

Parents low income did not have significant association in developing type 2 diabetic mellitus. The results was the same as previous research by Health Based Research showing most of diabetic patients had middle-high income (13). Other research (2010) said different result where family having low income was related to twice being mortality caused by type 2 diabetic mellitus (14). Other research mentioned low income area had 
bigger prevalence to be DM2 than high income area. It was difficult to state that low income had strong association in developing of DM2 because other factors affecting DM2 like obesity and low physical activity (15). Many respondents had low education. Previous research stated low education affected the low awareness in healthy life style and controlling the development of DM2 (16).

Head family working on agriculture area had to be risk of DM 2 by $47 \%$. It could be influenced by high stock of rice after harvest. They had high availability of food. The previous research said rice had high glycemic index around $73 \pm 4$ further influencing glucose metabolism (17). A research in Teheran showed high consumption in white rice affected the development of metabolic syndrome (18). Having $>4$ family members was related to the risk of DM2 by $32 \%$ than those $<4$ members. The possible reason was high volume in food availability of food and women also had more chance in consuming more food when preparing food(19).

Genetic factor had strong connection to be DM and having family history in type 2 diabetes mellitus was risk to be DM2 by 10.5 times bigger. Genetic and environmental factor had influence in development of DM2 (20). Smoking was not significant relationship in development of DM2. It was caused by the low proportion in smoking, $11 \%$ and $12 \%$ in case and control group. Therefore, It need more research to identify whether smoking was risk of DM2.

Food access had no significant association to be DM2. It caused by high expenditure on non food stuffs. In contrast to other, low access on food had risk to be DM2 by $44 \%$ (21). Culture, religion and traditional knowledge could influence food security, nutrition security shaping community food habit, food choice, distribution in household, feeding practice and health sanitation(22).

Food absorption showing nutritional status in family revealed it was risk to be DM2 by $62 \%$. On the other hand, type 2 diabetic mellitus could develop in low nutritional status. Some possibility was that low nutritional status was related to glucose intolerance(23). It can be inferred DM2 was related to low and chronic nutritional status and obesity called double burden malnutrition especially in developing country (24).

Physical activity was not be the risk of DM2. It was the same results as previous research (25). On the other condition, there was the fact that physical activity had protective factor in development of DM2 (26). Physical activity was not risk of DM2, but sedentary activity had important role in developing of type 2 DM (27).

\section{Food Security, Quality Diet, Obesity and Type 2 Diabetic Mellitus}

The previous research showed there were no variables related to DM2. Food security was not significant relationship. The other research in Canada stated food insecurity was higher in respondents in DM2(28). On the other had,food insecure family became risk factor of DM2 (29).

There were no respondents having good quality diet. It was the same as previous study in Baikpapan (30). The score of diet quality index having no significant relationship counted by Healthy Eating Index/HEI (31). Respondent also had low diet quality index by HEI (32)caused by low consumption compared with requirement in all food groups. Respondent with low quality diet was related to DM2 (33).

Obesity was not risk of DM2. It was the same result conducted in Sukoharjo, where obesity by body mass index was not related to obesity(34). However, central obesity was possible in developing in DM2 in Kulon Progo Regency. The previous study also said the same results (35).

\section{Factor Affecting The Development of Type 2 Diabetic Mellitus}

Based on logistic regression, family history was the only one factor to be DM2. Genetic factor could not be changed, but environmental factor including food pattern and physical activity decreased risk of DM2 (36).

Food security did not become risk of DM2, because genetic factor have big important role in the development of DM2. Research in Kulon Progo Regency involving patients suffering DM more than 1 years. So, food insecurity was possibly impact 
of chronic diabetic mellitus type 2 . Therefore, the next research about risk of food insecurity in development of DM2 have to be conducted precisely based on method, respondents and also analyzing others determinant factors including behavioral, environmental and biological factors.

\section{CONCLUSION AND RECOMMENDATION}

House hold food security was not risk factor of type two diabetic mellitus. Low quality diet was also faced by all respondents. Central obesity had opportunity to be risk of type 2 diabetic mellitus. And family history had strong relationship in DMT2 in Kulon Progo Regency.

Many factors was related to house hold food security hereafter affecting development off type two diabetic mellitus. Other factors included food pattern, obesity and low quality diet also affected DMT2. It was a challenge for nutritionist to prevent DMT2 in insecure family. Nutrition education based on balanced diet with prevent obesity by counting waist circumference and weight gain. Eating more fruit and vegetable based on local food seasonally. Respondents was suggested to choose cheap local food having cultural value. Respondent having DM2 should be manage their diet based on dietary recommendation.

\section{REFERENCES}

1. Anderson $\mathrm{SA}, \mathrm{Ph} \mathrm{D}$. Core indicators of nutritional state for difficult-to-sample populations. J Nutr. 1990;120 Suppl:1559-600.

2. Bickel G, Nord M, Price C, Hamilton W, Cook J. Guide to Measuring Household Food Security Revised 2000. Agriculture [Internet]. 2000;1-76. Available from: http://scholar.google.com/scholar? $\mathrm{hl}=$ en\&btn $\mathrm{G}=$ Search\&q=intitle:Guide+to+Measuri $n$ n+Household+Food+Security+Revised+2000\#0

3. Fitzgerald, N., Hromi-Fiedler, A., Segura-Pérez, S., Pérez-Escamilla R. Food Insecurity is Related to Increased Risk of Type 2 Diabetes Among Latinas. Ethn Dis. 2011;21(1):328-34.

4. Lipoeto NI, Wattanapenpaiboon N, Malik A, Wahlqvist ML. Nutrition transition in west Sumatra, Indonesia. Asia Pac J Clin Nutr. 2004;13(3):312-6.
5. Kosulwat $\mathrm{V}$. The nutrition and health transition in Thailand. Public Health Nutr. 2002;5(1A):183-9.

6. Kendall a VVE, Yd MO a, Frohgillo E a. Validation of the Radimer / Cornell Measures of Hunger and Food Insecurity. J Nutr. 1995;125(January):2793-801.

7. Noviani, Nor Eka; Kandarina, Istiti; Nisa' FZ. Ketahanan Pangan Rumah Tangga dan Akses Pangan sebagai Faktor Risiko terjadinya Diabetes Melitus Tipe 2. J Mitra Kesehat. 2018;1(2):117-24.

8. Kementerian Kesehatan RI. Keputusan Menteri Kesehatan Republik Indonesia Nomor 1995/ Menkes/SK/XII/2010 tentang StandarAntropometri Penilaian Status Gizi Anak. Jakarta; 2011.

9. World Health Organization WPR. The Asia-Pacific perspective: Redefining Obesity and its treatment. Health Communication Australia Pty Limited on behalf of the Steering Committee; 2000.

10. Kim S, Haines PS, Siega-RizAM, Popkin BM. The Diet Quality Index-International (DQI-I) provides an effective tool for cross-national comparison of diet quality as illustrated by China and the United States. J Nutr. 2003;133(11):3476-84.

11. Mcnaughton S a, Dunstan DW, Ball K, Shaw J, Crawford D. Dietary Quality Is Associated with Diabetes and Cardio-metabolic risk factors. Analysis. 2009;(6):734-42.

12. Ekpenyong CE, Akpan UP, Ibu JO, Nyebuk $D E$. Gender and age specific prevalence and associated risk factors of type 2 diabetes mellitus in Uyo metropolis, South Eastern Nigeria. Diabetol Croat. 2012;41(1):17-28.

13. Kesehatan BP dan P. Laporan Riset Kesehatan Dasar 2013. Jakarta: Balai Penelitian dan Pengembangan Kesehatan Republik Indonesia; 2013.

14. Saydah S. Socioeconomic Status and Risk of Diabetes-Related Mortality in the U .S . 2016;125(3):377-88.

15. Rabi DM, Edwards AL, Southern D a, Svenson LW, Sargious PM, Norton P, et al. Association of socio-economic status with diabetes prevalence and utilization of diabetes care services. BMC Health Serv Res. 2006;6:124.

16. Robbins JM, Vaccarino $\mathrm{V}$, Zhang $\mathrm{H}$, Kasl $S$ V. Socioeconomic status and diagnosed 
diabetes incidence. Diabetes Res Clin Pract. 2005;68(3):230-6.

17. Atkinson, FA; Foster-Powell, A;Brand-Miller J. International Tables of Glycemic Index and Glycemic Load Values : 2008. 2008;31(12):18-20.

18. Bahadoran Z, Delshad H, Azizi F, VIfdo SK, Ru $D$, Ehu ORZ, et al. White Rice Consumption is a Risk Factor for Metabolic Syndrome in Tehrani Adults : A Prospective Approach in Tehran Lipid and Glu- cose Study. 2014;17(6):435-40.

19. Rohrer, Lucia; Hersberger, Martin; von Eckardstein A. High density lipoproteins in the intersection of diabetes mellitus, inflammation and cardiovascular diseaseNo Title. Lipid metabolism. 2004. p. 269-78.

20. Park KS. The search for genetic risk factors of type 2 diabetes mellitus. Diabetes Metab J [Internet]. 2011;35(1):12-22. Available from: http://www. pubmedcentral.nih.gov/articlerender.fcgi?artid $=3$ 080574\&tool=pmcentrez\&rendertype=abstract

21. Edwards T. I Nflammation, P Ain , and C Hronic D Isease : a N I Ntegrative a Pproach. 2006;4(6):3-6.

22. Alonso EB. The impact of culture, religion and traditional knowledge on food and nutrition security in developing countries. 2015;(30).

23. Jauch-Chara K, Schmoller A, Oltmanns KM. Impaired glucose tolerance in healthy men with low body weight. Nutr J [Internet]. 2011;10(1):16. Available from: http://www.nutritionj.com/ content/10/1/16

24. Uwaezuoke SN. Childhood Diabetes Mellitus and the Double Burden of Malnutrition: An Emerging Public Health Challenge in Developing Countries. J Diabetes Metab [Internet]. 2015;06(09):2-6. Available from: http://www.omicsonline.org/ open-access/childhood-diabetes-mellitus-andthe-double-burden-of-malnutrition-an-emergingpublic-health-challenge-in-developingcountries-2155-6156-1000597.php?aid=59755

25. Valliyot B, Sreedharan J, Muttappallymyalil J. Risk Factors of Type 2 Diabetes Mellitus in the Rural Population of North Kerala, India : a Case Control Study. Diabetol Croat. 2013;2030(1):33-40.
26. Gill JM CA. Physical activity and prevention of type 2 diabetes mellitus. Sport Med. 2000;38(10):807.

27. Bozkurt A, Sahinoz T, Özgür S. Risk Factors Of Type-2 Diabetes In South-Eastern Anatolia Of Turkey. 2005;3(1):6-11.

28. ENZAGUCCIARDI JANETA.VOGT MARGARET DEMELO DES. Exploration of the Relationship Between. Diabetes. 2009;32(12):2218-2224.

29. Seligman HK, Laraia B a, Kushel MB. Food Insecurity Is Associated with Chronic Disease among Low-Income. J Nutr. 2009;140:304-10.

30. Gardiarini P. Tesis: Kualitas Diet, Sosio-Demografi, dan Dukungan Keluarga Hubungannya dengan Pengendalian Gula Darah pada Penderita Diabetes Mallitus Tipe 2 di Rumah Sakit Kanujoso Djatiwibowo (RSKD) Balikpapan. Mada UG, editor. Ygyakarta; 2014.

31. Murray AE, McMorrow AM, O'Connor E, Kiely C, Mac Ananey O, O'Shea D, et al. Dietary quality in a sample of adults with type 2 diabetes mellitus in Ireland; a cross-sectional case control study. Nutr J [Internet]. 2013;12(1):110. Available from: http:// www.nutritionj.com/content/12/1/110

32. Asaad G, Chan CB. Relationship of diet quality to food security and nutrition knowledge in lowincome, community-dwelling elders with type 2 diabetes mellitus: A pilot study. Can J Diabetes [Internet]. 2012;36(6):310-3. Available from: http:// dx.doi.org/10.1016/j.jcjd.2012.10.006

33. Fung. A prospective study of overall diet quality and risk of type 2 diabetes in women. Diabetes Care [Internet]. 2007;30(7):1753-7. Available from: http://diabetes.publicaciones.saludcastillayleon. es/content/30/7/1753.short

34. Trikoriati D. Faktor Risiko terjadinya Diabetes Mellitus tipe 2 pada Lanjut Usia di Kabupaten Sukoharjo Jawa Tengah. Universitas Gadjah Mada; 2011.

35. Rosyadi D. Tesis: Hubungan Obesitas dengan Kejadian Diabetes Mellitus Tipe 2 di Puskesmas Wates Kabupaten Kulon Progo. Universitas Gadjah Mada; 2013.

36. Romao I, Roth J. Genetic and Environmental Interactions in Obesity and Type 2 Diabetes. JAm Diet Assoc. 2008;108(4 SUPPL.):24-8. 